\title{
Ivorian Towns of the Inland, Put to the Test of Their Environmental Degradation: the Case of Daloa (West Center of Côte d'Ivoire)
}

\author{
Bolou Gbitry Abel \\ Jean Lorougnon Guédé-Daloa University, Ivory Coast \\ E-mail: gbitry2007@yahoo.fr \\ Gouaméné Didier-Charles \\ Jean Lorougnon Guédé-Daloa University, Ivory Coast \\ E-mail: gouam_didier@yahoo.fr \\ Bleu Dion Xavier \\ Jean Lorougnon Guédé-Daloa University, Ivory Coast \\ E-mail: xavierbleu103@gmail.com
}

Received: January 12, 2021 Accepted: February 9, 2021 Published: February 16, 2020

doi:10.5296/emsd.v10i1.18307ＵRL: https://doi.org/10.5296/emsd.v10i1.18307

\begin{abstract}
With its 258,509 inhabitants (INS, 2014. 27), Daloa, the third largest city in Côte d'Ivoire, has experienced an urban growth rate of $2.73 \%$ (op cites). But over the years, the locality has been confronted with an uncontrolled urban dynamic which has environmental repercussions on its landscape. Measures and actions are daily announced by the public authorities to eradicate this phenomenon, but the change is still virtual. This study aims to identify the persistence of environmental degradation in the city of Daloa. The methodology for conducting this study was based on a set of technical approaches. This is documentary research focusing mainly on scientific work and study reports addressing the issue of uncontrolled urbanization and its environmental effects. In addition to this approach, direct observation and interviews with local resource people were used. A questionnaire survey was also conducted with 373 heads of household using the probabilistic formula without
\end{abstract}




\section{Macrothink}

replacement in $1 / 3$ of the enumeration areas totaling 13 neighborhoods. The results show that the deterioration of the urban environment in Daloa is experienced by households in the form of pollution caused by rainwater, wastewater and sluices (47\%.), Pollution due to household waste (24\%), air (15\%) and noise (14\%) pollution. The factors are plural and reveal that 58\% of the households surveyed dispose of their used water (detergents, dishes) on the street and $48 \%$ dump household waste on the streets. The impact on the urban landscape is just as diverse and unpleasant. Rainwater on unpaved roads accelerates erosion. The flow of open sewage and piles of rubbish, undermine the aesthetics of the urban landscape of Daloa.

Keywords: Ivory Coast, Daloa, Environmental degradation, Urban dynamics, Urban landscape, Pollution

\section{Introduction}

The beginning of the 21st century marks the assertion of the South as engines of urbanization. This very sustained urbanization is reflected both by massive arrivals of populations from the countryside and by high birth rates within urban families, generally young. The rural exodus combined with demographic growth produces strong pressure in terms of access to housing and infrastructure (P. NEDELEC, 2018, p. 33)

The 21st century as the engine of Africa's urbanization is a reality. With an urbanization rate of $14.5 \%$ in 1950 , the urbanization rate reached $40 \%$ in 2010 , reaching $61.60 \%$ in 2050 (P. NEDELEC, 2018, p. 33). In Côte d'Ivoire, the urbanization rate fell from 5\% in 1950 to 39\% and $42.5 \%$ in 1988 and 1998, respectively, to reach 50.3\% in 2014 (INS, 1988, 1998 and 2014, p.27). This urban explosion is also noticeable in Daloa, a town located in the center-west of the Ivory Coast. With an estimated population of 258,509 inhabitants and 45,429 households (INS, 2014), it has an urban growth rate of $2.73 \%$. The locality is faced with an uncontrolled urban dynamic which is not unrelated to environmental problems KOUKOUGNON (2012, p.23). Despite the actions taken to preserve the city's environmental framework, the major trends in its degradation are irrefutable: illegal dumping of household refuse, defective sanitation networks, impassable traffic routes, etc. Therefore, the issue of environmental degradation in Daloa remains relevant.

\section{Methodology}

\subsection{Geographic Setting of the Study}




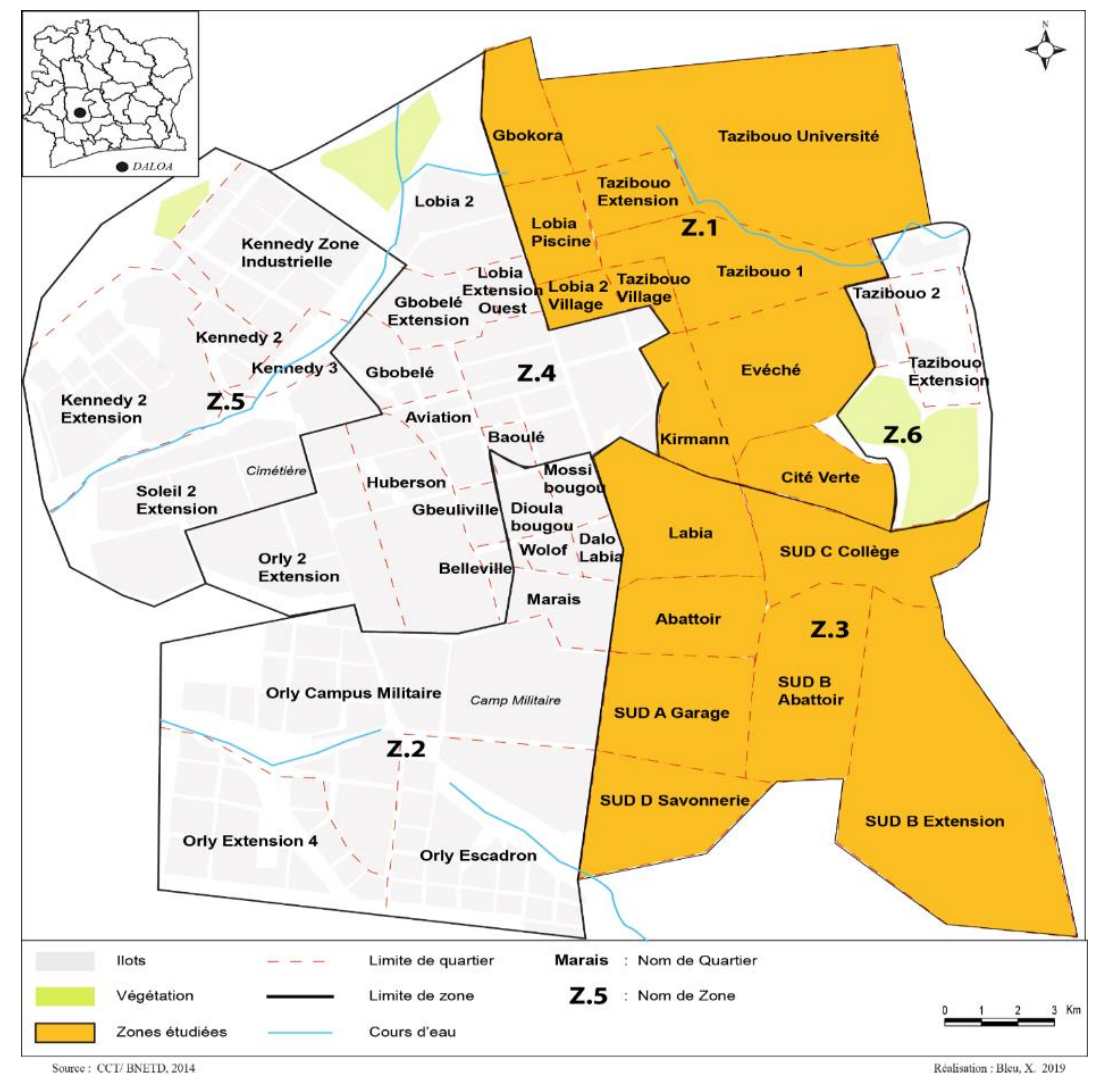

Figure 1. Presentation of the study area

42 districts divided into six counting zones make up the city of Daloa. Each enumeration area includes a residential district, an evolving district and a precarious district. Each spatial entity brings together sociodemographic, socioeconomic, sociological and environmental sensitivities. This nomenclature is established by the INS as part of general population and housing census operations. As it was impossible to carry out the study on all six zones, 2 counting zones were chosen for sampling (Zone I and III) in view of operational constraints and environmental realities in the town of Daloa. These areas were chosen to understand the heavy trend of environmental degradation in the city of Daloa because they better explain the phenomenon.

\subsection{Data Collection Method}

The data collection was initially focused on documentary research; On the one hand, the documentary research focused on the consultation of theses, dissertations, scientific articles, study reports and on the other hand, on administrative archives. The sought information concerned the forms of degradation of the urban environment, their spatial distribution, the factors of the degradation of the urban environment and their impact on the living environment of the populations. Overall, the consulted documents were in the documentation centers of the University Jean Lorougnon Guédé (UJLoG), the documentation center of Calasanz, the French institute of Abidjan plateau, the Institut of Tropical Geography (IGT); in the Ministries of Environment and Sustainable Development (MEDD), Health and Sanitation 


\section{Macrothink}

(MSA), Construction, Housing, Sanitation and Urban Planning (MCLAU); at the Ivorian Antipollution Center (CIAPOL) and at the Daloa technical town hall. The documentary approach was supplemented by webography (internet). The practical phase of data collection combined direct observation, interviews and questionnaire. The direct observation was the opportunity to travel through the city in general and in particular the thirteen (13) districts of the 2 zones in order to understand the environmental realities in the so-called residential districts (zone I) and the so-called working-class districts (zone III). Also, these areas were the subject of our study because they contain varied and heterogeneous environmental realities. The main entities observed are mainly the landscape, equipment, infrastructure (sanitation, health, education, water, roads) and habitat (living environment).A questionnaire for heads of households focused on the forms of environmental degradation they face, the factors behind this degradation and the impact of this phenomenon on their quality of life. Interviews were also carried out with a manager from each of the following six (6) administrations: MEDD, MSA, CIAPOL, MCLAU, Daloa technical town hall. In total, 379 people were surveyed in this study, and this during the months of January, February and March 2019. To determine the size of the sample of households to be surveyed within the 13 neighborhoods comprising the two zones, the probabilistic no discount method was applied.

\section{Results}

\subsection{A multiformity of the Degradation of the Urban Environment Induced by Plural Factors}

Environmental degradation in Daloa takes various forms and affects various media, both natural (water, air, soil) and artificial (living environment, infrastructure). This degradation is above all due to pollution (Figure 2).

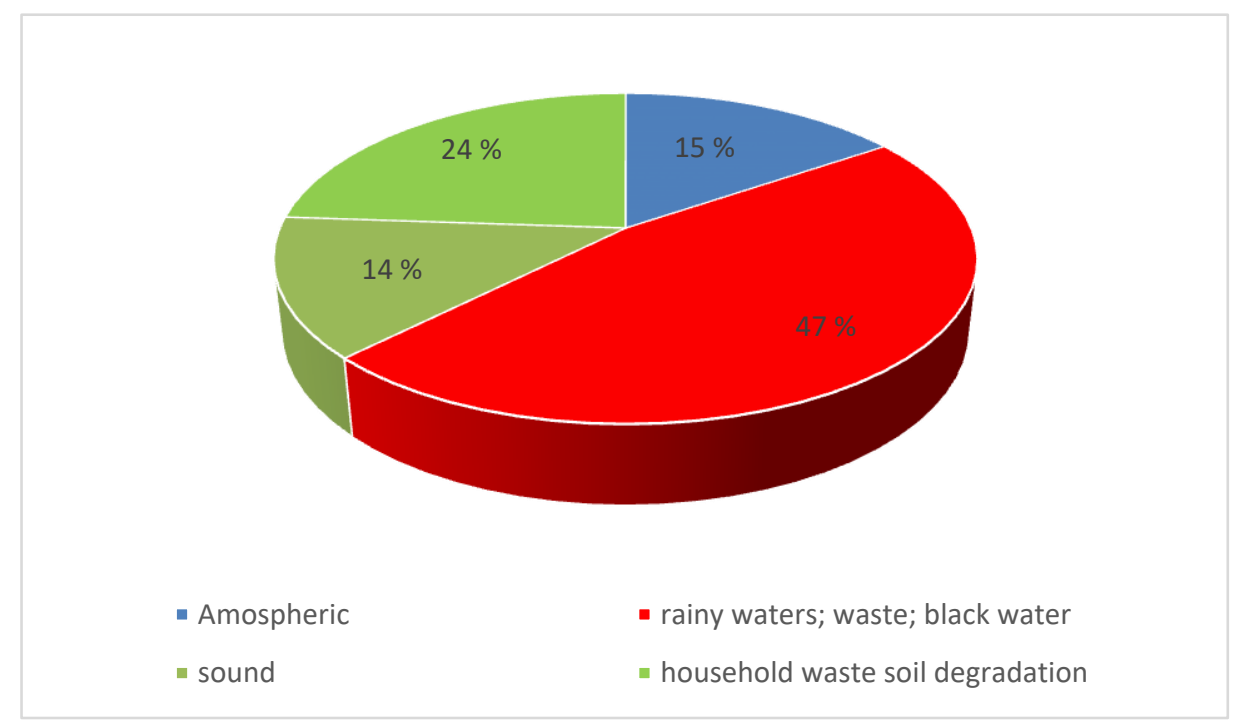

Figure 2. Extent of environmental degradation according to households surveyed in 2019

Source: Our surveys, January-June, 2019

Pollution caused by rainwater, wastewater and valves is criticized by households at $47 \%$. 


\section{Macrothink}

Their particularity is that they start from homes to alleys and vice versa. In addition, $24 \%$ indexed the pollution due to household waste which ends up being buried alone in the ground over time. As for atmospheric pollution (air), 15\% noted it. They complain about the dust particles released by roads, most of which are unpaved. Finally, $14 \%$ of the surveyed households also noted the noise pollution resulting from numerous noisy activities in the vicinity of dwellings.

3.1.1 The Poor Treatment of Rainwater, Wastewater and Valves as a Source of Degradation of the Urban Environment

- The thorny problem of sewage disposal

The method of wastewater disposal remains an important element in the process of environmental degradation. Thus, in zones I and III of the city of Daloa, this water is evacuated in four ways: to the street, in septic tanks, soaks and gutters (Figure 3).

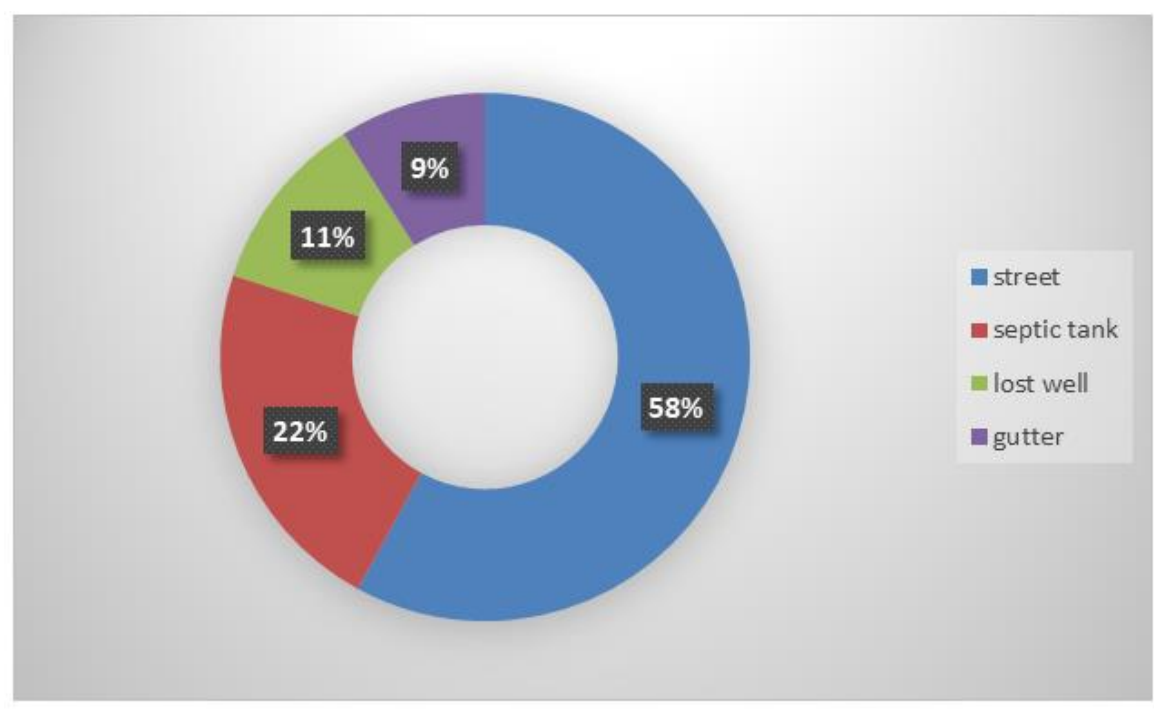

Figure 3. Wastewater disposal method in 2019

Source: Our surveys, January-June, 2019

The results indicate that $58 \%$ of the surveyed households evacuate their wastewater in the street, $22 \%$ in septic tanks, $11 \%$ in soaker wells and $9 \%$ say they evacuate it in gutters. But in the studied areas, the phenomenon is not understood in an egalitarian way (Figure 4). 


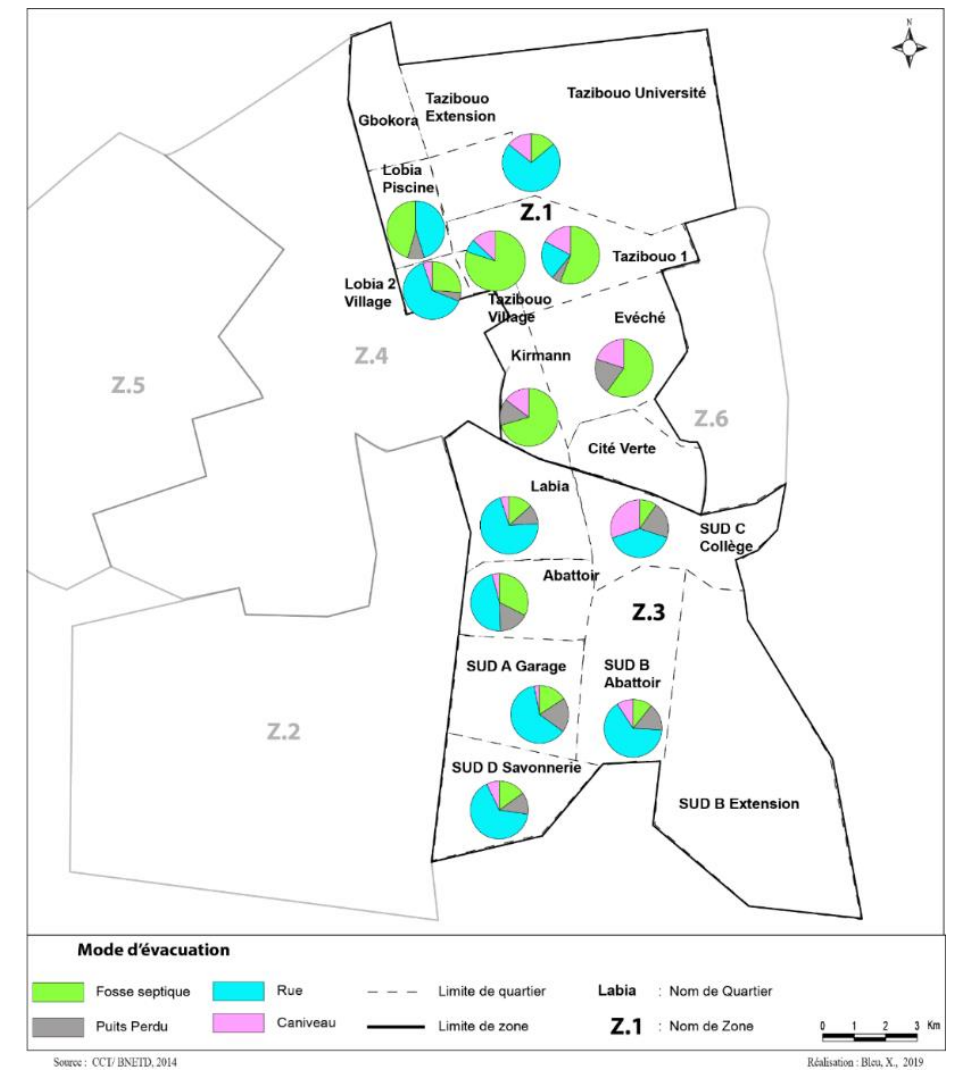

Figure 4. Distribution of the wastewater disposal method by district in 2019

Figure 4 shows that in the districts of Abattoir 1, Sud A (Garage), Sud B (Abattoir 2), Sud C (Fadiga), Sud D (Savonnerie), Labia, Lobia 2 and Tazibouo Extension at least $50 \%$ of households that they evacuate their waste water in the street. The proportions are respectively: Slaughterhouse 1 (81.33\%), South A (61.90\%), South B (65.33\%), South C (57.14\%), South D $(65.38 \%)$, Labia (72\%), Lobia $2(63.16 \%)$ Tazibouo Extension (57.43\%). As for the districts, Evêché (75\%), Kirmann (62.5\%), General Staff (80\%) and Tazibouo 1 (56.10\%), households evacuate their wastewater in septic tanks. The soaker wells and gutters are mainly used in the South $\mathrm{C}$ district with $28.57 \%$ and $42.86 \%$ respectively. In zone 3 , the street remains the preferred household network for the evacuation of wastewater (Figure 5). 


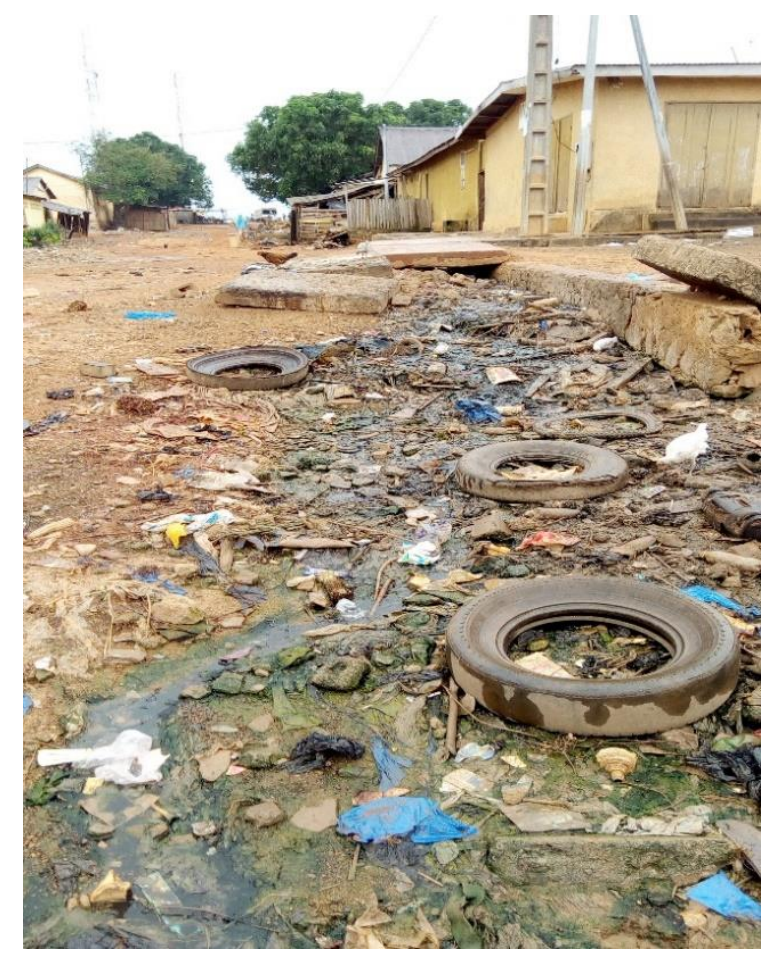

Figure 5. Wastewater flow and valves mixed with domestic waste

Figure: The authors, March 2019

This Figure shows a street in the Abattoir 1 neighbourhood, where you can see the waste water run-off in the middle of the street, which looks like black water in terms of colour. The whole thing is mixed with a pile of rubbish. This leads us to believe that this street is a dump tolerated by everyone.

The method of emptying the latrines

The emptying of toilets and latrines constitutes a phenomenon of degradation of the urban environment. Indeed, during this activity, foul odors are released from human waste that pollute the atmosphere. Thus, the methods of emptying the latrines identified during the household survey are the use of emptying trucks, either through soaks, or they are connected to the open gutter. The emptying method by using an adapted truck is more practiced by households in the areas surveyed. Thus, $43 \%$ of households use this means, $41 \%$ soak-up wells and $16 \%$ open-air gutters. Households in the South C (68\%), Evêché (73\%), Kirmann (61\%), Piscine (62\%), Lobia 2 (62\%), Tazibouo 1 (74\%) and General Staff (79\%) districts no longer use trucks as a means of emptying latrines and toilets. In the Abattoir 1 and Tazibouo Extension districts, $65 \%$ of the surveyed households proceed by connection to the open gutter to empty their latrines. On the other hand, this way of doing things concerns only $1 \%$ of households in the Tazibouo 1, Evêché and Tazibouo Etat-Major districts. The proportions of this practice in the South A, South B, South D, Piscine, Labia and Lobia 2 districts are respectively $12 \%, 10 \%, 12 \%, 18 \%, 11 \%$ and $5 \%$. Households using soaks for emptying are 


\section{Macrothink}

mainly located in the South A (68\%), South B (59\%), South D (55\%) and Labia (82\%) districts. Households use the most appropriate technique for emptying their latrines and toilets, however the wrong options contribute to the degradation of the urban environment of Daloa.

\subsubsection{Inappropriate Management of Household Waste in Neighborhoods}

The proliferation of household waste remains the most visible form of the degradation of the urban environment. . In fact, it is possible to observe piles of rubbish in the corners of houses and in the streets of neighbourhoods. Speaking of the possession of rubbish bins, $41 \%$ of the households surveyed said that they had them, compared with $59 \%$ of households who said that they did not have any. There is an indescribable lawlessness everywhere around households and on the streets garbage storage. The odors that emerge become unbearable at times.

\section{A heterogeneous way of disposing of household waste}

The method of disposing of household waste in the town of Daloa has been criticized as a factor in the degradation of the urban environment. Thus, streets, lowlands or ravines, incineration and the service of pre-collectors, constitute the main modes of household waste disposal. The results of the investigations indicate that $48 \%$ of the households surveyed evacuate their waste in the streets, $30 \%$ by the service of the pre-collectors, $13 \%$ in the shallows and $9 \%$ by incineration. The most worrying phenomenon is the proliferation of household waste along roadsides (Figure 6).

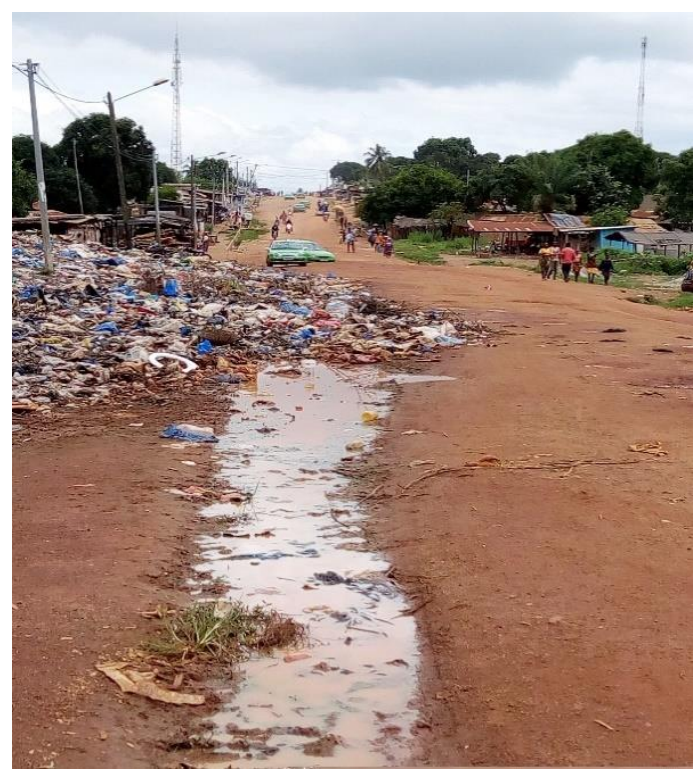

Figure 6. Roadside rubbish dump in the Garage neighbourhood

Figure: The authors, March 2019

On this road in the garage district, we can see an informal deposit of household refuse that overflowed from its border site to spread out on the roadway. Unsanitary water is released there. 


\section{Macrothink

The different proportions by district are highlighted by the graph below

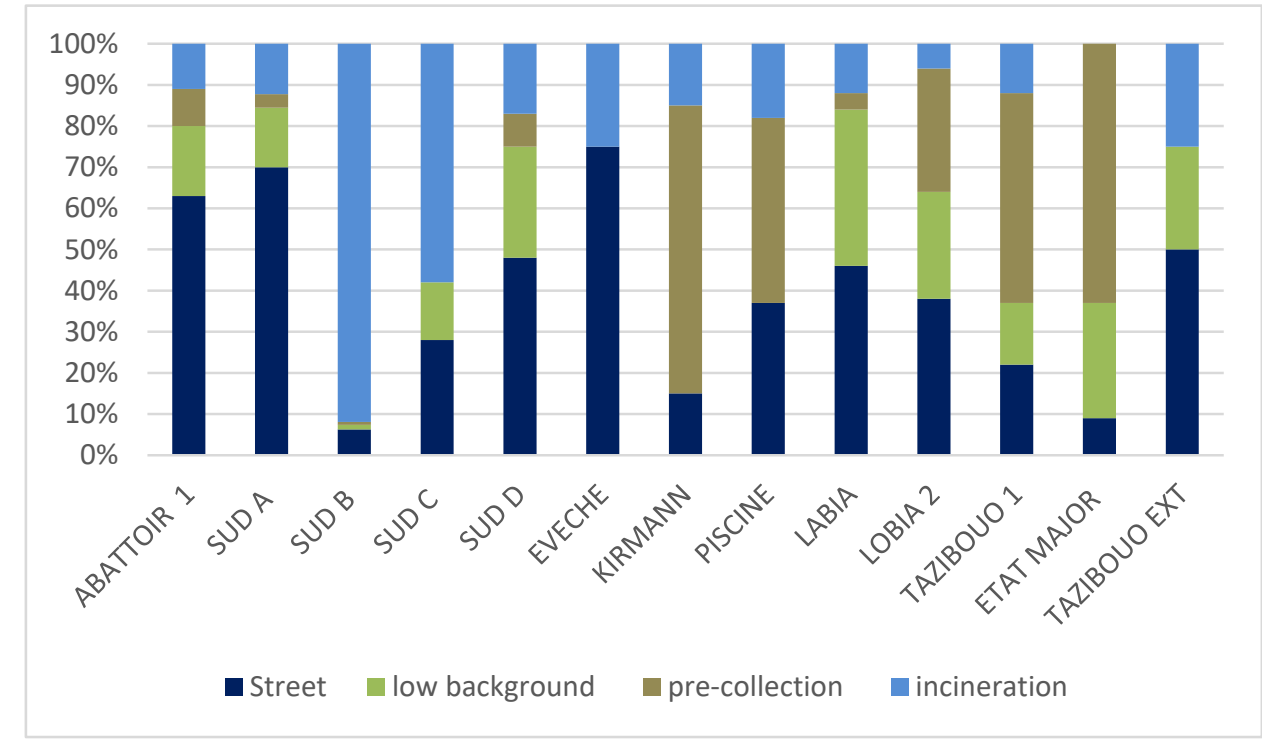

Figure 7. Distribution of households by type of household waste disposal in 2019

Source: Our surveys, January-June, 2019

The Figure shows that households in the Abattoir 1 (62\%), Sud A (62\%), Sud B (68\%), Labia (52\%) and Tazibouo Extension (50\%) districts dump their household waste in the street. As for those in the Evêché (75\%), Kirmann (75\%), Swimming pool, Tazibouo 1 (52\%) and General Staff $(65 \%)$ districts, they hire the precollector for the collection of their rubbish. in the districts of Abattoir 1 (18\%), South A (10\%), South B (12\%), South D (28\%) Tazibouo 1 (12\%), Labia (30\%), Lobia $2(25 \%)$ and Staff (18\%), the lowlands serve as dumping grounds. However, no household in the Sud C, Evêché, Kirmann and Piscine neighborhoods mentioned the use of the shallows as a place of garbage disposal. In all of the surveyed districts, the responses of households in favor of incinerating their garbage are low $(9.12 \%)$. However, 50\% of households in the Sud C district (Fadiga) incinerate their garbage. The data show that a relatively large proportion of the populations of the neighborhoods studied exhibit behaviours that are harmful to the environment. The non-use of the places indicated by the municipal authorities for the deposit of household waste shows the acuteness of the unsanitary living environment of the surveyed populations in zone 3.

3.1.3 Degradation Attributable to Road Infrastructure, Atmospheric Pollution and Noise Pollution

According to the technical services of the town hall, the urban road network has a total length of $526.09 \mathrm{~km}$. The paved road in good condition which is $48.52 \mathrm{~km}$ long; the paved road in poor condition has a length of $23.88 \mathrm{~km}$; the unpaved road in poor condition totals $254.6 \mathrm{~km}$; the undeveloped road of $199,09 \mathrm{~km}$. Therefore, it emerges that $91 \%$ of the roads are in poor condition or not developed; Only $13.76 \%$ of the road is asphalted, $1 / 3$ of which is in poor condition. The districts of Zone 1 concentrate most of the roads in good condition and the 


\section{Macrothink}

districts of Zone 3 concentrate most of the undeveloped and / or in very poor condition. Thus, there are $8 \%$ of paved roads and good condition in zone 1 against $5.76 \%$ in zone 3 . Stripping, lack of maintenance, silting up are the ills of asphalted roads and gullying. erosion explains the poor condition of the unpaved roads (Figure 8).

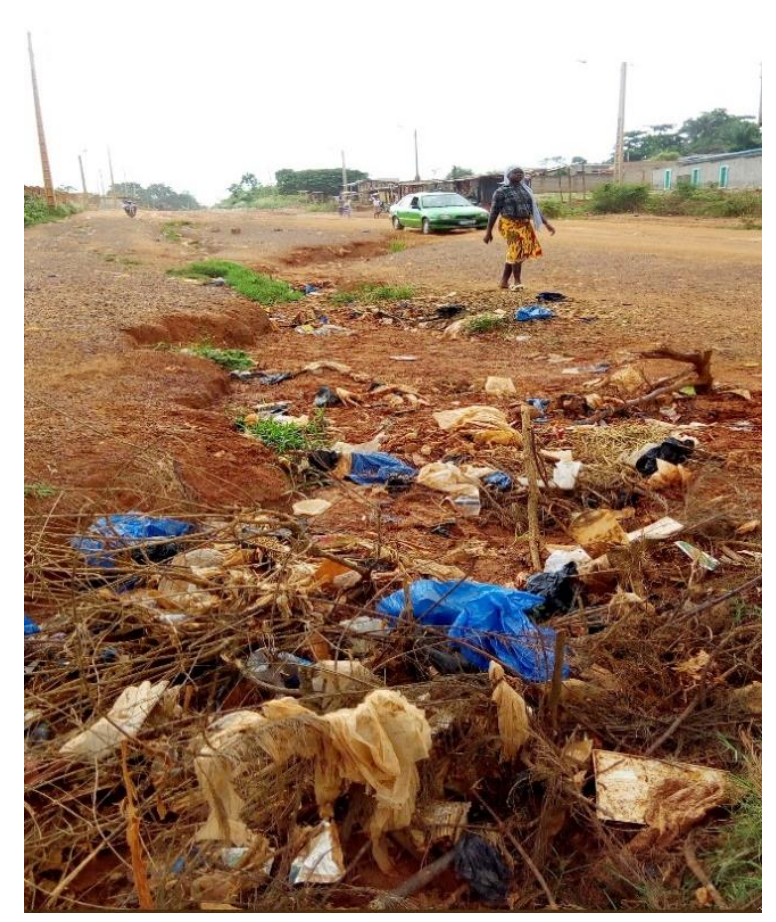

Figure 8. Degradation of an unpaved road in the South D district

Figure: The authors, March 2019

In the long run, not asphalting the tracks leads to their degradation or the production of dust clouds during the dry season.

Of the $15.47 \%$ of households decrying atmospheric (air) pollution, $14 \%$ note that it is due to dust particles mainly emanating from unpaved roads and $1.47 \%$ decry the incineration of waste. Regarding the $13.65 \%$ of respondents complaining of noise pollution, $12.70 \%$ decry the anarchic installation of economic activities and $0.95 \%$ the lack of recreational space.

\subsection{Socio-environmental and Health Impacts}

\subsubsection{Populations Exposed to Socio-environmental Risks}

In the face of the generalised degradation of the urban environment in Daloa, the households surveyed indicated that they had suffered several prejudices. They were grouped into 4 categories (Figure 9). 


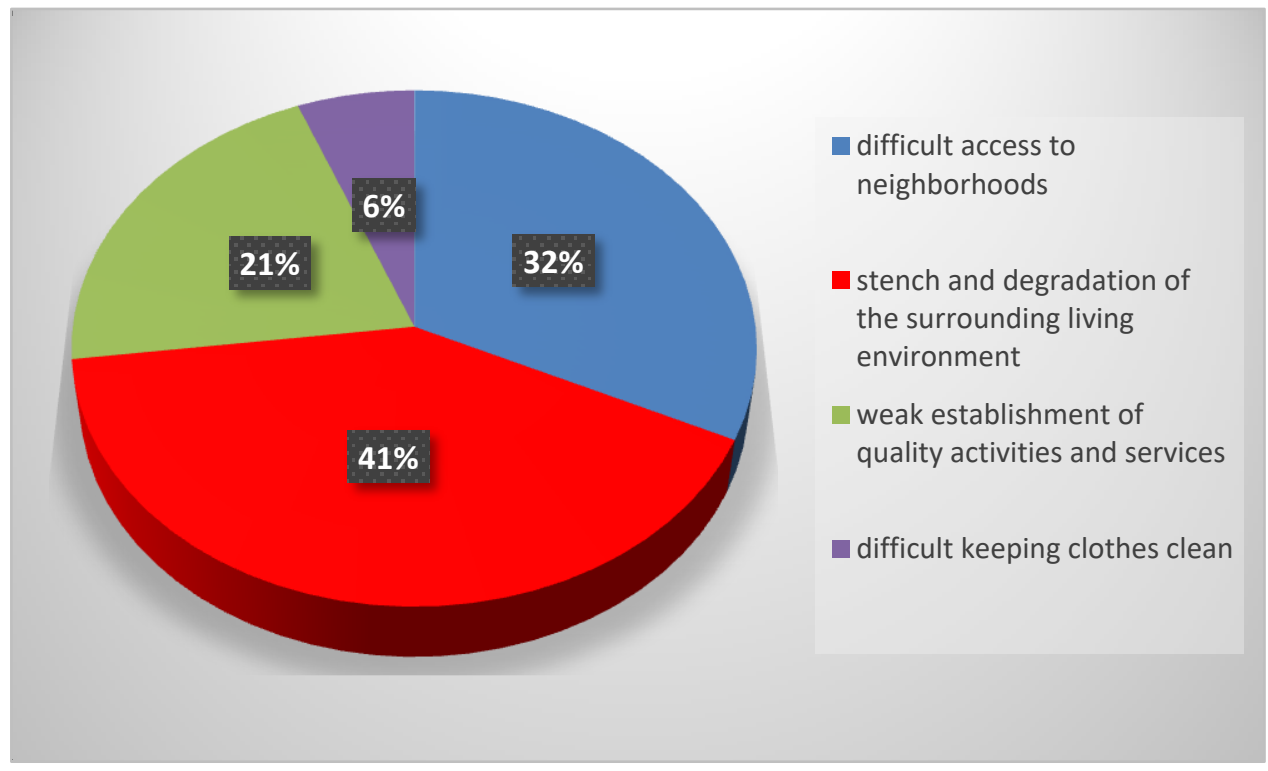

Figure 9. The consequences of environmental degradation in 2019

Source: Our surveys, January-June, 2019

The stench and the degradation of the ambient living environment is mainly presented by $41 \%$ of the respondents a major incidence of pollution in Daloa. This is followed by difficulties in accessing neighborhoods $(32 \%)$ due to the impraticability of most of the roads. The weak establishment of modern service activities resulting from this pollution is revealed by $21 \%$ of housewives since the stench and numerous dust particles thwart their attractiveness. Households also complain of the difficulty in keeping their clothes clean due to the numerous particles of dust or mud during the rainy season and dry season. The built habitats in non-aedificandi areas are the most exposed to degradation of the living environment (Figure $10)$.

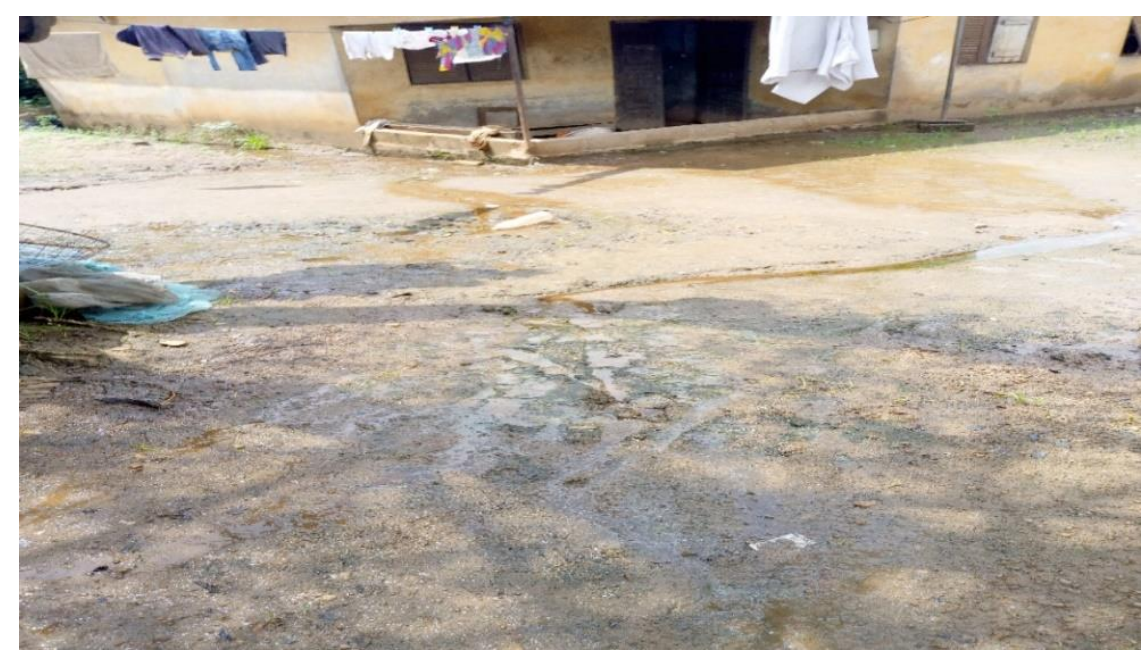

Figure 10. Stagnant water in a yard in the Abattoir 2 district

Figure: The authors, March 2019 


\section{Macrothink}

This Figure shows a house located in a lowland in front of which the rainwater stagnates. This situation presents an unpleasant state of the habitat. Thus, the inhabitants constantly live in dampness and mud, putting them in a state of vulnerability. Also, this state of affairs poses a problem of movement in the yard. In general, the stagnation of rainwater is feared by households at $38 \%$ while the effect of erosion is denounced at $62 \%$ by said households. Thus, these natural effects are more feared in the South A (73\%), Abattoir 1 (54\%), South D (63\%) and Lobia 2 (54\%) districts with regard to erosion. As for stagnant rainwater, these are the districts of Abattoir 1 (69\%), South A (55\%), Swimming pool (51\%) and Tazibouo Extension $(63 \%)$. In other districts, these so-called effects have been less recent. The stench and the degradation of the surrounding living environment also undermine the aesthetics of the urban landscape (Figure 11)

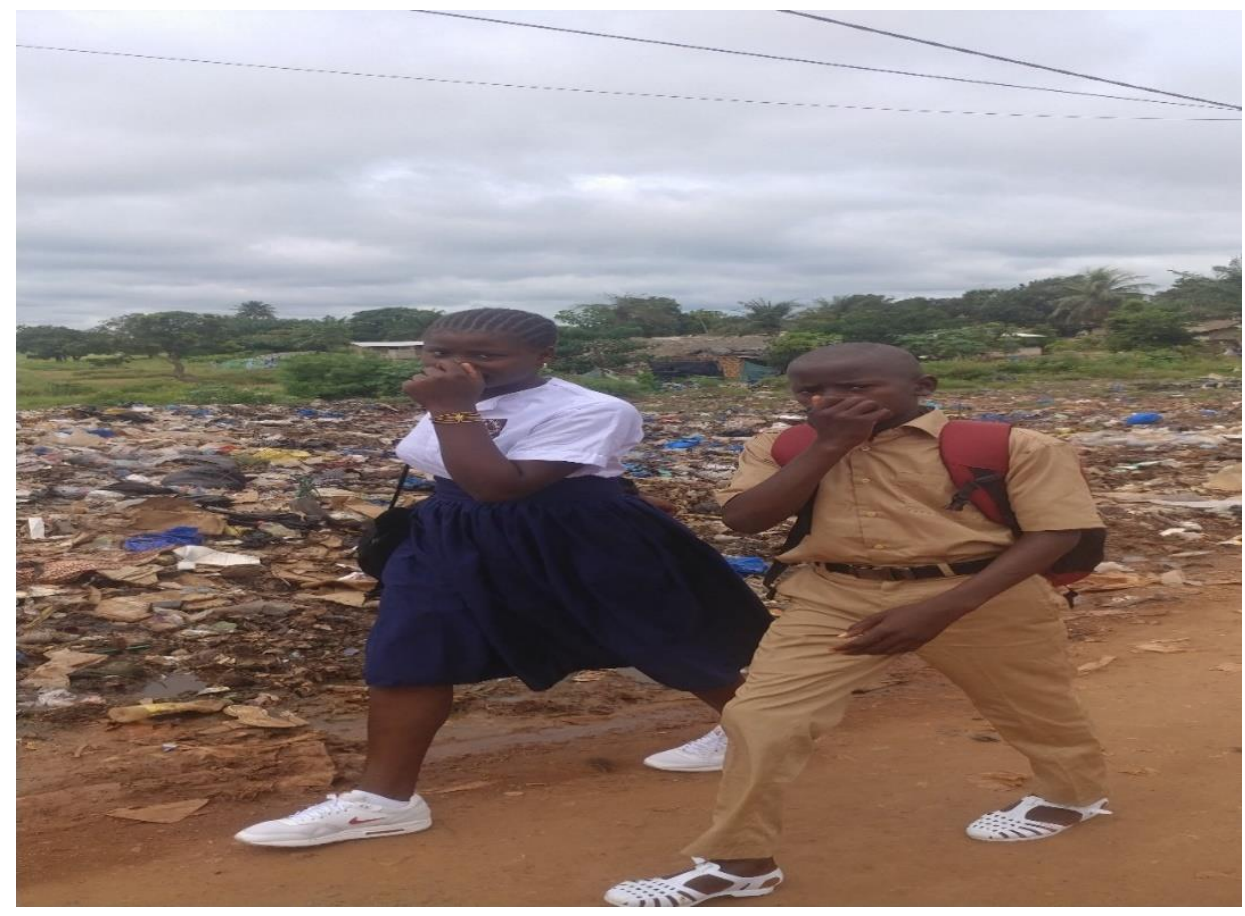

Figure 11. Stench from littering garbage dumps in Lobia 2

Figure: The authors, March 2019

This Figure taken at Lobia 2, highlights the illegal garbage dumps littering the edges of streets and giving off foul odors. The image also shows passers-by (students) visibly suffering from the stench emanating from the pile of rubbish.

\subsubsection{Increased Health Risks}

The current state of the environment in Daloa contributes to the proliferation of diseases. Indeed, the hygienic practices of the populations in such a quasi-vulnerable environment are inadequate with environmental standards. This results in environmentally related diseases. Thus, the survey conducted among households to find out the occurrence of diseases to which they are more victims, it appears that malaria, acute respiratory infections (ARI) and diarrhea 
are recurrent. The results indicate that $64 \%$ of households are affected by malaria against $27 \%$ of ARIs and $9 \%$ of diarrhea. It should be noted that the preponderance of these diseases depends on the different districts of the city. These spatial disparities in pathologies can be seen in Figure 12 below.

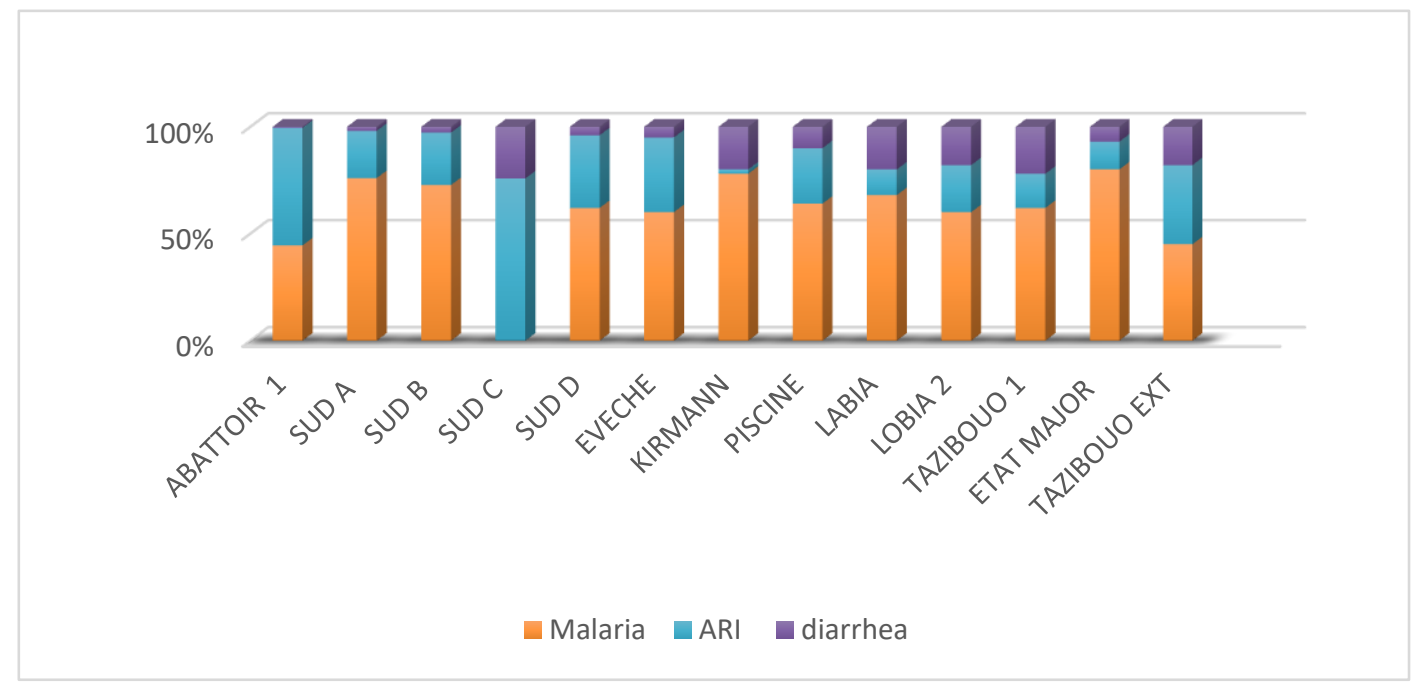

Figure 12. Cases of illnesses observed in households by district in 2019

Source: Our surveys, January-June, 2019

Specifically, the three main diseases (malaria, ARI, diarrhea) are observed in all neighborhoods. Indeed, the prevalence of malaria is denounced in most neighborhoods at at least $60 \%$. However, there is an absence of this infection in the South C district (Fadiga). As for ARI, this infection is more marked in the South C district (78\%) and weak in the other districts. Finally, concerning diarrhea, it is less singled out by the households surveyed. It is weak in all neighborhoods.

Theoretically, the evolution of pathogenic cases of malaria is linked to the multiplicity of stagnant water in connection with the non-use of impregnated mosquito nets by the neighboring populations. As for ARIs, they are caused by increased dust and smoke in the air. Infection of populations with ARI results from aspiration of infected air particles. Finally, the resurgence of diarrheal diseases is the result of contact between wastewater and water resources (well water, surface water in the water table). This type of contact increases the risk of contamination of populations when they use these resources (consumption, swimming, food, bath, laundry, dishes, etc.)

In short, all these socio-sanitary dysfunctions are as many effects which characterize the neighboring populations. It is in the face of this dramatic situation that the local authorities of the city of Daloa will take action to improve the environmental framework. 


\section{Discussion}

The objective of this study is to identify the problem of the persistence of environmental degradation in Daloa, a town in the interior of Côte d'Ivoire. This locality is one of the 10 most important localities of Côte d'Ivoire from a socio-economic point of view. For KOUKOUGNON (2012, p. 23), this question suggests that the town of Daloa is experiencing accelerated spatial-demographic growth. As such, one can affirm, echoing VENNETIER (1990, p. 59-64) and OUMAROU (2018, p. 130), that the increase in its population entails risks of environmental degradation while exposing it to massive dangers.

The results of the study revealed a multiformity of the degradation of the urban environment induced by multiple factors. The poor treatment of rainwater, wastewater and valves is decried by $47 \%$ of respondents. In their studies on Adjamé in Abidjan and N'Djamena in Chad, TUO (2010, p. 10) and SIMEU-KAMDEM (2018, p. 149) note the absence and inefficiency of wastewater and rainwater treatment systems as one of the major causes of the increase in insalubrity in these cities. Aspect underlined by N. NEDELEC (2018, p. 33) in a more general approach to urbanization in cities in developing countries. However, Q. YAO-KOUASSI $(2010$, p. 8) points out that the issue of insalubrity in cities in the South is not only due to the urbanization trajectory - it also resides in a political will to propose solutions for the management of urban waste. For this author, the aim is to review the policies of Ivorian cities by resorting to a more pragmatic urban governance with regard to the issue of household waste management. Furthermore, the results of the study indicate that $43 \%$ of households use latrines and adapted trucks for emptying, $41 \%$ use waste wells and $16 \%$ use open gutters.

In addition, the poor management of household waste was decried by $24 \%$ of respondents. On this issue, SIMEU-KAMDEM (2018, p. 150), referring to the case of the city of N'Djamena, only points out that $17 \%$ of waste water is evacuated through gutters or gullies. All the rest is dumped in the street, in the concessions or even on some unoccupied plots. Also, cities are the cause of the concentration of this waste in one place, which overloads the capacity of local ecosystems to assimilate them. Moreover, such practices also have a social cost due to the nuisance produced. For ATTAHI (2006, p. 11), the problem of household waste is 'one of the big black spots in the municipal management of cities. All mayors have lost the battle over household waste. They are dedicated to the collection of this rubbish. This is understandable, given the continued unsavoury behaviour of some households. In this respect, DIA and TENDENG (2018, p. 188) explain these household practices by the difficult transition from rural to urban lifestyle. This study also found that $48 \%$ of households dump domestic waste in the streets. As for air and noise pollution, respectively $15 \%$ and $14 \%$ of the households surveyed present them as determining factors in environmental degradation. Overall, the results of the study agree with those of GOGOUA (2013, p. 53) who quoted HaJle and Bruzon, claiming that environmental degradation poses many problems. The priority problems are insufficient collection of solid and waste wastes, pollution of surface water. And the second-tier problems concern groundwater, air pollution, noise pollution and natural hazards. 
Regarding the socio-environmental and health impacts, $41 \%$ of respondents complained of the stench and the deterioration of the living environment, $64 \%$ of malaria, $27 \%$ of respiratory infections and $9 \%$ of diarrhea. This is why DERYCKE (1973, p. 310), wonders. For him, the urban space, which is home to nearly two / thirds of humanity and most of the production units, has become the seat of tension, nuisance, insecurity and cost, the magnitude of which leads one to wonder if urban life does not have more disadvantages than advantages.

The health issue is all the more worrying as CAIRNCROSS et al (2004, p. 45), affirms that environmental factors are the cause of $21 \%$ of diseases in the world, and this proportion is even greater in developing countries. According to these authors, 1.7 million young children die each year from diarrhea due to unsafe drinking water supply, inadequate sanitation and hygiene. 1.4 million childhood deaths from respiratory infections are attributable to atmospheric air pollution. WHO-UN Habitat, (2010, p. 98), confirms this by indicating that environmental factors are responsible for more than $21 \%$ of the global burden of diseases.

\section{Conclusion}

This study has shown, that the environmental landscape of Daloa is subject to various forms of environmental degradation, resulting from multiple factors. The main causes of environmental degradation identified are the problems associated with the poor management of rainwater, wastewater and valves. The proliferation of household waste and its poor management are also a formidable factor. To this was added the anarchic installation of economic activities causing noise pollution in certain neighborhoods. Finally, the many unpaved roads produce significant amounts of dust, here called air pollution. The disadvantages of the degradation of the environment on the city of Daloa are noticeable both on the populations and on the space. Populations are infected and the urban landscape has lost its appeal. The phenomenon is evolving exponentially while initiatives are less and less. No one should wait for the worst before taking appropriate large-scale measures.

\section{References}

Attahi, K. (1995). The waste problem in Abidjan and its historical basis. BNETD, Abidjan. p. 29.

Cairncross, S., O'neill, D., Mccoy, A. et al. (2004). Health, Environment and the Burden of Disease. Department for International Development. p. 61.

Derycke, P-H. (1973). Urban dynamics and regional economic development. p. 869-886.

Dia, A. H., \& Tendeng, S. J. (2018). The dual management of household waste in Ziguinchor. Between municipal care and household practices. under the direction of Michel SIMEU-KAMDEM and Touna MAMA, The policies of the city in question (In search of better urban governance in sub-Saharan Africa), Cameroon, L'Harmattan, p. 171-191.

Gogoua, G. E. (2013). Urban growth and environmental degradation on the ivory coast: Case of the city of Issia, single thesis, Institute of Tropical Geography. UFHB of Cocody, Abidjan- Ivory Coast. p. 336. 


\section{Macrothink}

Environmental Management and Sustainable Development

ISSN 2164-7682

2021, Vol. 10, No. 1

INS. (1988, 1998 and 2014). General Census of Population and Housing (RGPH). Republic of Ivory Coast.

Koukougnon, W. G. (2012). Urban environment and access to drinking water: case of Daloa (center-west of the Ivory Coast). single thesis, University of Cocody, Abidjan, p. 416.

Nedelec, P. (2018). Urban geography, Paris, Armand Colin. p. 253.

Oumarou, A. (2018). Flood prevention in Niamey, an entry point for an analysis of urban governance. In M. Simeu-Kamdem \& T. Mama (Eds.), The policies of the city in question (In search of a better urban governance in sub-Saharan Africa) (pp. 127-147). Cameroon, L'Harmattan.

Paquot, T. (2016), Urban Earth (Five challenges to become urban on the planet). Paris, La Découverte. p. 243.

Simeu-Kamdem, M. (2018). The gutters in the cities of sub-Saharan Africa: a plague of contemporary urbanization. In M. Simeu-Kamdem \& T. Mama (Eds.), The policies of the city in question (In search of better urban governance in sub-Saharan Africa) (pp. 149-169). Cameroon, L'Harmattan.

Tuo, P. (2010). Environmental remediation and management in the town of Adjamé: the case of Williams town. master thesis. p. 102.

Vennetier, P. (1990). Urbanization and living environment. Paris, Notre Librairie. pp. 59-64.

Who-Un, H. (2010). Water, hygiene and sanitation and population health in Nouakchott (Mauritania). Vertigo, p. 257.

WORLD BANK. (2009). Urbanization an environmental force. New York: Oxford University Press for the World Bank.

Yao-Kouassi, Q. C. (2010). In search of synergy for the management of household waste in Côte d'Ivoire: case of the district of Abidjan. Unique doctoral thesis in geography, Le Mans, University of Maine. p. 305.

\section{Copyright Disclaimer}

Copyright for this article is retained by the author(s), with first publication rights granted to the journal.

This is an open-access article distributed under the terms and conditions of the Creative Commons Attribution license (http://creativecommons.org/licenses/by/4.0/). 